\title{
POSTCOLONIAL MINSCAPES AND CONTEMPORARY CARIBBEAN REGGAE
}

\author{
Chris Egharevba ${ }^{1}$, \\ Kufre Egharevba ${ }^{2 i}$ \\ ${ }^{1}$ Associate Professor, \\ University of Uyo, \\ Uyo, Nigeria \\ ${ }^{2}$ Lecturer, \\ University of Uyo, \\ Uyo, Nigeria
}

\begin{abstract}
:
That Caribbean music forms and their sonic influences are steeped in a vibrant culture of social awareness and ethereal consciousness is incontestable. Roots reggae's protest appeal, rhythmic syncopations, and deeply religious impulses attest to a rich, aware and reactive tradition forged from post-slavery legacies to engage the rotary realities of mid-late 20th century West Indies. Contemporary Caribbean reggae follows in this tradition. With a very deep root in the religious beliefs of the people, Reggae music developed as the medium for the masses to cope with the social, economic and political realities of the day in Jamaica and many other Caribbean communities. Consequently, the Reggae music has proven to be relevant as long as there is suffering and injustices among the masses, this is not to say Reggae music does not reflect some other aspects of life. The emphasis in this paper is to trace the history and development of Reggae, especially its connection to the Rastafari lifestyle. The paper considers some key pillars of Reggae music, which includes but not limited to the believe by the Rastafarians that Haile Selassie is the black Jesus which Marcus Garvey had prophesied about and that he is bringing salvation to the black community in Jamaica.
\end{abstract}

Keywords: postcolonialism, contemporary Caribbean reggae, consciousness, roots reggae

\section{Introduction}

There is no discourse about Reggae that would not take into cognizance the nation Jamaica and especially the activities of the Rastafarians in the country in the early $20^{\text {th }}$ century. Meanwhile, the Rastafarian movement and by extension the reggae movement cannot be explained outside of the nationalist clamor that saturated Jamaica and other black communities around the world at this period. In his dissertation titled, "Roots reggae from Cape Town to Helsinki", Tuomas Järvenpää traces the global nationalist clamor of people of African origin to the activities of

i Correspondence: email kennosa02@gmail.com 
Marcus Garvey, a wealthy business man from Jamaica whose influence was as far as to the black community in the US. Garvey's aim was to unify all Blacks around the world under one political ideology; hence he founded the Universal Negro Improvement Association (UNIA) $)^{\mathrm{ii}}$. No doubt the activities of Marcus Garvey also raised a black/race consciousness in different places in Jamaica, including Kingston, the home of the Rastafarians.

Consequently, Tuomas notes that "In the 1930s, the early Rastafarian preachers made a theological connection between Marcus Garvey and Haile Selassie, and saw Selassie as the black Christ, whose coming Garvey had allegedly prophesied." iii The ideals of the Rastafarians became more or less a religion for the people, with foundation also in the Christian faith, as it is believed that Haile Selassie is the descendant of the union between Solomon and Queen Sheba. In the midst of this, "by the end of the 1950s there emerged an exclusively Rastafarian music form, known as Nyahbinghi..." iv which also became the foundation for what is today referred to as roots reggae.

Reggae or roots reggae (for the sake of differentiation with contemporary reggae-the focus of the study) developed into an organic, distinct genre in the 1960s in Jamaica, a period of noteworthy revival in modernism after a drop in the 1930s, with the region forcefully easing into its post-colonial vision at the behest of an undying colonial heritage. As such, it can be identified as modernist. Contemporary reggae as produced today, with the innovations in lyrical direction and sound production and radical aestheticism as well as the pervading tradition within which it exists is more postmodernist than otherwise. Despite this significant gap - as postmodernism is on impulse taken as a radical revision of all things modernist - the differences between roots reggae and contemporary reggae are almost thematically and in terms of motif immaterial. It would seem that the sort of innovation in contemporary reggae typical of postmodernist art forms is limited to its sonic configuration, while its lyrical and thematic directions remain almost undisturbed. To start on how contemporary reggae as a contemporary form fitted with postmodernist peculiarities continues within the distinctive province of reggae (with its conscious, religious, and protest trappings complete) requires a significant detour into the intricate divide between postmodernism and modern art generally, which promises to yield the essential/instructive points to start off this interrogation.

\section{Postmodernism and modernist arts: Continuities}

Contrary to what might be said to generally obtain on the subject of contemporary (postmodernist) art and their disruptive countenancing of antecedent art/literary patterns, contemporary art forms do continue in those directions typically associated with older and modernist forms. The argument is often laid out with the logic that some of the foremost features of the postmodernist tradition are highlighted as indices of overt departures: postmodernism or postmodernist forms are characterized by aleatory approaches, eclecticism, and substantial incorporation of the techniques of parody and pastichev. However, these-although only a

\footnotetext{
ii Tuomas Järvenpää, "Roots reggae from Cape Town to Helsinki"

iii Ibid, 46

iv Ibid, 45

v As defined by J.A Cuddon. See Cuddon J. Anthony, A Dictionary of Literary Terms Literary Theory, (West Sussex, UK: Blackwell Publishing, 2013).
} 
significant few - do not extensively dichotomize modernism and its 'post' variant, especially in ways to lead us to the hypothesis above. Features of aleatory writing and eclecticism do not signify the performance or presence of any radical division because eclecticism, which essentially marks fragmentation and variety, is a principal characteristic of modernism, deducible from various literary highlights like the works of modernist writers Virginia Woolf, DH Lawrence, Thomas Eliot, James Joyce, or Dambudzo Marechera. Fragmentation defined various aspects of modernist art, from the works of Pablo Picasso and Georges Braque to that of William Faulkner or the Jazz compositions and popular music of 1890- to later 1930s and then again in the 1960 $\mathrm{s}^{\mathrm{vi}}$, especially with the innovations that led to new ways of envisioning rhythm, harmony, and aestheticism to achieve striking degrees of impressionism, reflexivity, and collage of previously thought impossible elements.

The flaw in the demarcation between modernism and postmodernism with regard to these parameters is further revealed by emphasis on the aleatory technique-through which chance, contingency, and probability attain aesthetic significance-as uniquely postmodernist. Dadaists are modernist examples of artists who copiously render in use this approach vii, a matter Peter Barry comfortably lays to rest in his position on postmodernism. Additional, parody and pastiche are as effervescent within the modernist tradition of unorthodoxy and anti-established art procedures as they are within the postmodernist. Nihilism and the rejection of order as traditionally conceived are significant touchstones in defining either modern or postmodern art. In light of this, it is never enough to hold postmodernism and its art forms as alienated entirely from the modernist tradition through subversion. One can follow in the path of two wellconceived modes of delineation to grasp why: firstly, that postmodernism and modernism are not successive. By striking out temporal continuity, this position gives credence to the argument that certain aspects of modernism are postmodernist. The implication of this is the underscoring of experimentation ${ }^{\text {viii }}$ - which births radical breakaways from established conventions - as a superior marker of postmodernism, to put it broadly. While alluring, this position glosses over a crucial fact: Postmodernism shares a similitude of posturing with modernism that is overtly political, even if actualized differently. Both traditions are offspring of a renaissance initiated by the restive prevalence of a new collective consciousness. Modernism in its subversive approach to experimentation seeks to break away from the past-which Mary Klages says it presents fragmentally, mourning and lamenting $i^{\mathrm{ix}}$ - in order to bury it eternally. Postmodernism on the other hand attempts to approach and redefine the same past in its own fragmentary, intrinsically inconsistent and indeterminate terms. As such, it is not enough to use experimentation as yardstick as it reinterprets modernist experimentation as postmodernist.

\footnotetext{
vi It is held within certain circles that modernism receded considerably after the 1930s to resurge back in the 1960s. See Peter Barry Beginning Theory: an Introduction to Literary and Cultural theory, (Manchester: Manchester University Press, 2002).

vii Peter Barry, "Beginning Theory,"

viii Jean-Francois Lyotard's seminal work The Postmodernist Condition, which set the tone and trajectory of postmodernism as a discursive critical mode of understanding can be said, in lieu of arriving at a summarizing philosophy, to be an overt attestation to his rejection of his perceived attempt at censoring experimentation.

ix Mary Klages, Literary Theory: A Guide for the Perplexed, (New York: Continuous International Publishing Group, 2006).
} 
The other approach, which coheres with the aforethought, is to see postmodernism and its art forms as a re-creative continuation of the modernist project. This way, we would be in concordance with the literary acceptance of postmodernism (its art and philosophies inclusive) as having grown out of the bounds and tendencies of modernism. This position finds crucial authority in Lyotard's conception of postmodernism as "embracing a set of practices, strategies and techniques that either repudiates modernist tendencies or develop those tendencies in extreme forms"x. It also affords us the luxury of circumventing the grey areas problematizing the historical or temporal origins of postmodernism, which as Klages argues is hard to pinpoint. It is to this end that this study comfortable rests on the continuities that exist between postmodernism and modernism, thereby dissociating itself from the way most scholars and researchers view these concepts independently. Perhaps, it is in order to state early that Reggae, in this study, is also considered as the melting point between what is modern, the postmodern and the postcolonial, dissecting the relationship that exists between these three through Reggae history and development.

\section{Reggae: Roots and Contemporary}

With these in mind, it is easier to reflect on how contemporary reggae, essentially a postmodernist form - not solely by virtue of its temporal placement, but by the innovations that upbraid it as a distinct art form and the realities it fragmentally grapples with - continues in/with the same defining turns and currents that set apart roots reggae, its modern antecedent, as a communicative aural art. Reggae (whose temporal-bound forms will be, for the purpose of analysis, referred to roots reggae and contemporary reggae $)^{x i}$ grew as a natural response to a fading but acutely felt legacy of Western incursion. Jamaica, the historical home of reggae, attained Independence in 1962, and has had its fair share of political tumult, with its landscape and social political space embroiled in class and identitarian struggles.

The late relinquishment of power to the people of Jamaica in 1962, and indeed the Caribbean, ensured that the country remains till date an island of desperate survivalists, forced capitulations, unusual cleavages and methods of survival, contradictions, and ironies. James Winders, reflecting on these ironies and contradictions, reflects on the material metaphor and visible binarism between Kingston, the home of white colonizers, and Trenchtown, a chain of shanties, where (ex)-colonized peoples live $e^{x i i}$. Both metaphor and binarism are expressed by the presence of the stately homes of the whites on a hill overlooking Trenchtown, "one of the worst slums in the Western Hemisphere"xiii, a fact not hidden by its name which serves as a sort of tribute to its exact nature. Reggae is thoroughly Trenchtown as it is Jamaican or Caribbean; it is so because it fittingly cushions the effects of a rough transition from colonialism to freedom - which

\footnotetext{
x Jean-Francois Lyotard, The Post-modern Condition: A Report of Knowledge, (Massachusetts: University of Massachusetts Press, 1984), 84.

xi When a dichotomizing approach is required, roots reggae or contemporary reggae will be expressly referred to. But in the case where the mother form is referred to absent comparison, reggae will be used.

xii James A. Winders, "Reggae, Rastafarians and Revolutions: Rock Music in the Third World", Journal of Popular Culture 17.1 (1983): 62-73.

xiii Ibid., 62.
} 
is essentially neo-colonial - provides the needed safe space for voicing and existing, and records the realities of the drifters and the lower class Jamaicans residing in slums. Appropriately coined by Winders, it is the music of displaced rural Jamaicans who have withdrawn or fled into the slums in escape of a much more frightful rural poverty ${ }^{\mathrm{xiv}}$. It is Caribbean not only for its Jamaican or Black Diasporic syncretistic roots, but for the fact of its presently being a staple within the entire Caribbean region and for its mediumistic provisions that allow those of the Caribbean to unearth coping mechanisms within it.

Reggae is how the lower economic class of Jamaica copes with the realities of colonization, which caused a series of dismal living circumstances. It produced sharp economic distinctions, power inequalities, and material disparities that not only burficated the region into unequal halves (proletariat and bourgeoisie, whites and black/coloureds, upper and lower classes, Rastafarians and other West Indians, rundown shacks and tourist-beaches) but also survived into the postcolonial Caribbean, maintaining conditions of coloniality as seen in the differences between the stark city-slums and the oft-visually projected idyllic Caribbean scenery, between the Rastaman - the living metaphor of repression - and the Caribbean intelligentsia or the police who are often custodians of hegemonic (coloniality) authority, or in reggae terms downpressors. Creation of alternative sites of expression to maintain visibility and sanity and that can serve as vehicles of resistance to those realities became natural responses. One of such creations is reggae. Music in the West Indies is often more than a sonic material for the reason that it affords access to unmanned spaces where agency is derived and engineered. Correctly held by William Henry, musical cultures in the Caribbean provides access to alternative world view that enhances the accessing of spaces where Caribbean blacks and coloreds can achieve conscious representation in ways that rival previous public invisibility. In his words, black music, which is what reggae is, "often spoke to the lived experiences of the disenfranchised in a racist society, and thus furnished a site for various types of inter/intra-cultural exchanges to take place, enabling them to debate and discuss their own 'problem' status in a language owned and controlled by them"xv. Reggae's influence has been traced to Black American music rock and roll ${ }^{\mathrm{xvi}}$ and rhythm and blues and also Caribbean Skaxvii. Still, the cross-border syncretistic influences within the Caribbean Black Diaspora and between the Caribbean and the Black American space have not militated reggae from growing to become a distinct form, one globally known for its acute emphasis on issues of justice, capitalism, unity, and freedom and for its political orientation. More than this, it also accommodates spiritual cleavages as seen in the dynamics of its rendering and association with the Rastafarians, who are seen as a major cultural and political force in the Caribbean ${ }^{x v i i i}$ and who also espouse religious sentiments and groins for the return of the Black messiah to free them from Babylon - a succinct religious metaphor for all things undesirable ${ }^{\mathrm{xix}}$.

xiv Ibid., 63.

xv William L. Henry, "Reggae, Rasta, and the Role of the Deejay in the British Black Experience", Contemporary British History 26.3 (2012), 355: 355-373.

xvi James Tracy, "Popular Communication and the Postcolonial Zeitgeist: On Considering Roots Reggae and Dub", Popular Communication 2.1 (2005): 21-41.

xvii Stephen King and Richard J. Jensen, "Bob Marley's "Redemption Song": The Rhetoric of Reggae and the Rastafari" Journal of Popular Culture 29.3 (1995): 17-36.

xviii Ibid.

xix Winders "Reggae, Rastafarians and Revolutions"; King and Jensen "Bob Marley's Redemption Song". 
The Rastafarians have been called the "leading critics of the Jamaican government"xx for their vocal expressions of dissatisfaction with neo-colonialist manifestations in the Caribbean and sustained criticism of oppression, racism, and maintenance of the white and black divide wherever they are found, Britain, Canda, West Indies or the United States.

Reggae's ancestral ties to the Rastafarians expressly instruct on its political and religious structuring. The Rastafarians', Rastas or the Rastaman's criminal profile, as upheld by the authorities, is a sanctioning of the Rastafari counter culture. This counter culture is located within the ideological provisions of reggae. Although a blanket statement, Pryce's assertion that "almost all the Reggae singers in Jamaica had either been delinquents or ex-hustlers who came from particularly impoverished backgrounds"xxi holds a rather significant illumination. The Rastafari have existed as far back as the early $1900 \mathrm{~s}^{\mathrm{x} x i i}$. But not until the 1960s did reggae mature enough to enter the mainstream black musical culture in the Caribbean, enough to displace earlier musical forms, become an export capable of rivaling even bauxite, and to be distinctly received as music of protest.

Reggae's roots in the dawning of the postcolonial reality meant that it partook in and was forged from the dying embers of colonialism. Like the phoenix that it was, it formed from the ashes of a past that refused to expire. The framework of poverty and oppression within which it grew contoured it uniquely to the Rastafarian experience, which basically is of police brutality, public scorn, distorted portraiture as ganja-smoking cultists, gangstas and dropouts, and refusal of their spiritual longing toward repatriation ${ }^{x x i i}$, restoration and redemption, as seen in their philosophy of the return of the black messiah and their devotion toward the Haile Selassie persona, the late Ethiopian emperor from whom the group name draws linguistic and etymological influences - Ras Mekonnen Tafari-and to whom all divine reverence is accorded. Reggae, thus, became a mode of expression, of voicing out the desire to subvert the realities of Babylon, their default metaphor for the colonial and postcolonial/neocolonial reality, and to escape into Zion, the Rastaman's paradisal home. Owing to their constant political subversive stance and their reliance on reggae to express these acts, reggae songs are populated with the ideas of Rastas.

Reggae, by growing out of the slums and into the hands of the Rasta, became a heavily socio-conscious material. It laid bare the neocolonial framework snuffing life out of the proletariat while also capturing the agitations and survival strategies of the Rastas who belong to and speak for that category. Reggae's import is partially tied to its accessibility in those areas of palpable illiteracy where it can break out space for succor. In the words of King and Jensen, "the music acts as a catharsis which helps free people from the problems of the external world"xxiv. The music provided avenues for public registering of subversive opinions while also sheltering the dissenting voice from direct reprisal. Roots reggae, the modernist form that grew in the 1960s and 1970s, performed by heavyweights such as Bob Marley and Peter Tosh (amongst others) and

\footnotetext{
xx Ibid., 62.

xxi Ken Pryce, Endless Pressure: A Study of West Indian Lifestyles in Bristol, (Bristol: Bristol Classical Press, 1986$), 154$.

xxii Ibid; James "Popular Communication and the Postcolonial Zeitgeist".

xxii See Winders "Reggae" for more on the longing and denial of repatriation for Rastafarians who longed to be united with Africa otherwise called Zion, where they thought is home and Haile Selassie who is seen as the messiah. xxiv King and Jensen, "Bob Marley's 'Redemption Song'", 19.
} 
referred to as such for its reliance on African syncopated rhythms, percussive style, and cultural retained materials in the Caribbean, continues this decipherable and counter-hegemonic rendering of the postcolonial imaginary in the postmodernist fashion.

\section{Roots or Contemporary Reggae: The Rasta(man) Remains}

Reggae's lyrics and sound are testamentary to a foundational credo made manifest by its status as a vehicle of freedom. Its sonic configuring and lyrical direction particularly attest to this status, a phenomenon James refers to as reggae's unique combination of communicative elements ${ }^{\mathrm{xxv}}$. The communicative elements are a range of expressive metaphors, symbols, and performative idioms achievable in or distinct to reggae, defined by how they are set sharply against an untoward postcolonial reality. These idiomatic symbols range from the engineering of the religious into the material, as seen in the metaphoric and literal deployment of biblical Babylon and Zion in characterizing postcolonial realities and the desire for the utopian, to the invocation of Jah, Haile Selassie or the Rastafari imaginary in combating the demons of society and the self.

Reggae is seen as the music of the Rastafarians because it assisted in the expansion of the movement. Its emergence in the 1960s meant that it housed and propagated the philosophy of the Rastafari, especially through the actions of maestros like Bob Marley, who popularized the genre. King and Jensen hold Marley and his music as significant forces in the growth and reach of the movement; while Davis and Simon assert that the Wailers through their music thrust the Rasta worldview into the heart of the global arena, piquing people's interest and provoking people into states of enthusiasm on the Rastafari mode of survival: prayer, chants, and smoking of weed ${ }^{\mathrm{xxv}}$. Owing to its use by Rastas as a communicative medium in reaching the world and their inner souls, reggae became associated with the Rastafari, and the more reggae propelled Rastafarian ideologies through the deliberate workings of culturally conscious artists like Bob Marley, the music propelled the Rastafarian image and movement into the global arena, where

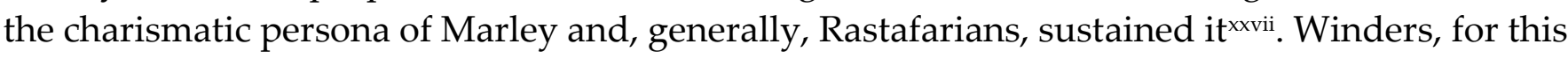
reason, calls their music some sort of Rastafarian sermon than actual popular songs.

So, while there might not be a unified Rastafarian theology as Winders claim, there is a suffusion of Rastafarian imaginary and metaphor in reggae that supports the position of a common approach to postcolonial imagining and lyrical engagement. The reworking or associable affixing of religious symbolism to or in appraising and combating material realities is distinctively reggae, most especially in its idiomatic sense. The Rastafarian solution to social ills and neocolonial repression is easily identified as a trope in reggae: love, unity, or repatriation to

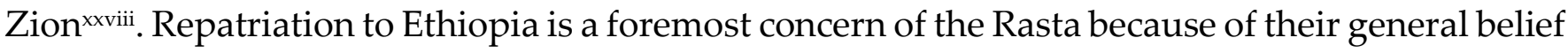
in Africa, Ethiopia, as the home of the Black Man. Another foremost concern is their belief in being lost captives in Babylon (a religiously allusive symbolism to the condition of enslavement and the postcolonial condition of class repression, white oppression, and neoenslavement/capitalism. Unlike a strong sentiment in the Caribbean that espouses sole Caribbean

\footnotetext{
xxv James "Popular Communication and the Postcolonial Zeitgeist".

xxvi Stephen Davis and Simon Peter, Reggae Bloodlines, (New York: Anchor, 1977).

xxvii See King and Jensen "Bob Marley's Redemption Song".

xxviii Ibid.; Winders "Reggae, Rastafarians and Revolution".
} 
and Diasporic fidelity, clamoring for a boycott of undue romanticization of Africa as motherland ${ }^{x x i x}$, Rastafarians see their presence in the Diasporic world as forced, repressive, and due for deliverance. This holds true in the way the Jah image is invoked in reggae.

In Jah Cure's "Lion in the Jungle", there is the explicit reference to Selassie as the singer asserts himself as a soldier in 'Jah army'. This status fits with the revolutionary persona of the reggae artist; it presents him as a voice incapable of being repressed, which is what reggae music essentially does: voicing the militancy of the oppressed against hegemonic postcolonial systems. Cure's deployment of this religious affiliation, especially from a combative stance, ties neatly with the tone of the music, which pays fidelity to reggae's original structuring. Selassie Haile is held by Rastafarians as God ${ }^{\mathrm{xx}}$. His sobriquet is, among others, Lion of the Tribe of Judah, Power of the Trinity, Elect of God, and King of Kings. The revelation story that presents an undefeatable army of God's children and the idea that Rastafarians see themselves as a lost people in an alien land, like the biblical Israelites are explicitly threaded into Cure's lyrics. It is not surprising that Cure aligns himself with this army in a military fashion or that the song is a self-reassuring profession of strength and indefatigability in the face of oppression.

Cure's titling of the song "Lion in the Jungle" confirms this position. The jungle is synonymous to the conception of the Caribbean by the Rastafari as Babylon for its repressive tendencies. Babylon after all is the home of systemic oppression and their perpetuators. Not only were scores of Rastafarians denied repatriation during the government of Prime Minister Michael Manley who opposed the desire for Rastafarians to return to Ethiopia; they have been subjects of police brutality, public contempt/disrespect, and physical brutality. In shedding explicit light on the repressive situation of the Rastas, Winders claims that "In the 1950s Rastas were often arrested, and sometimes flogged and forcibly shaved. Rastas even charged that in Trenchtown the police deliberately burned many children to death"xxxi. Cure's continuous reference to himself as the Lion, an attempt at subverting the public imaging of the Rastafarian follows in the selftherapeutic approach Rastafarians have toward reggae, which has always been seen as mode of externalizing personal experiences. One of such is the continued disrespect and attack on the Rastafari, as seen in Cure's lyrics: "They try, they try / No matter what they do, can't take my crown / They try, they try / Yes, I know they still can't bring me down".

The 'they' been referred to by Cure are the Babylonian forces, the cultural and sociopolitical high and mighty. Those who by default see people like Cure as vermin, a condition Cure purposively subverts with the panther metaphor. He sings "I'm the lion in the Jungle", an emphatic testament to his power to discard his enemies: "I'll send them all running/ Hear me roar". Cure's association with the Lion symbol and emphasis on his crown is reflective of the Rastafarian reliance on the legitimacy of Haile Selassie as the Lion of the Tribe of Judah, the Imperial insignia which has the panther symbol and a crown on its head, and their desire to be left alone, as exhibited by the movements of Rastafarians at one time to the hills of Jamaica to establish the

\footnotetext{
xxix See Robert E. Fox, "Diasporacentricism and Black Aural Texts", in The African Diaspora: African Origins and New World Identities, eds. Isidore Okpewho, Carole Davies and Ali Mazrui, 367-389. (Bloomington: Indiana University Press, 1984) for arguments on the rejection of African as source-identity in the New World.

xxx King and Jensen "Bob Marley's 'Redemption Song',"

xxxi Winders "Reggae, Rastafarian and Revolution," 64
} 
Pinnacle ${ }^{x x i i}$, away from public eye and the sustained raids of the police as well as their desire for repatriation. Pervading Cure's lyrics is a double tone of plea and threats: he warns that he is the lion in the jungle and he is wide awake, ready to hunt his detractors, while he also begs to be left alone lest he devours them because he cannot be brought down. The marshalling of a history of Rastafarian struggle, projected through reggae, is well threaded into Cure's lyrics. To them he says "...Let Sleeping lions lie"; after all, he is a soldier in Jah's (a shortened form of reference to Selassie Haile) army.

Cure's reference to Jah and the religious allusion as well as representations of the Rastafarian imaginary are familiar communicative elements in roots reggae. Bob Marley's songs, and those of his generation, are famous for their deployment of reggae as an expressive medium for personal issues and their working of these issues into the fabric of the society in such a way that it resonates beyond the individual into the collective. We see the same level of allusive engineering in Natty King's "No Guns to Town": Midway into the song, he implores listeners "to seek Rastafari strength". Why? To the Rastafarians, as worked into the song by Natty King, "He's the omnipotent". To the Rastafarian, Jah is the embodiment of goodness, strength, love, life. Owing to the continued use of the Rastafari as a signification of an unending source of inspiration among the Rastafarians, the Rastafari essence has been bifurcated into three symbolic functions: Jah as quintessence of goodness and love; as protector and guide; and the gateway toward a return to Zion, the Rastafari paradise ${ }^{\mathrm{xxxiii}}$.

Natty King preaches love in the same song, decrying boastfulness, intimidation and evil, which has perforated the Caribbean. His emphatic reliance on the Rastafarian ethos is espoused in several lines of the song: "Should a bring love come to town, yeah". His repetition of this line in several ways in the song lends credence to the submission on the continuance of the Rastafarian worldview and culture beyond temporal boundaries. Jah's deployment as a symbol of love or counter-hegemonic force or liberating strength or the reference to the postcolonial Caribbean terrain as Babylon or the Jungle is copiously present in a lot of Marley's songs ${ }^{\mathrm{xxxiv}}$. In "Love Is" by Jah Cure, we are exposed to the Rasta's emphatic offering of love as a solution to Third World and, generally, global problems. In the intro to the lyrics, he starts on a reassuring note: "Yeah you know, Rasta live / Universal sign of love / Love is the answer my friend / And love is the only way". Of course, needless to say is the continued use of the distinctive patois and heavy percussions or syncopated rhythms peculiar to reggae that was characteristic of roots reggae, although the reliance on electronic instruments to provide the backing track and contemporary synthesizers give the songs a postmodernist allure.

Natty King's and Jah Cure's lyrics, despite having a $21^{\text {st }}$ century concern, offer significant and abundance traces of the Rasta, their views, and overarching philosophy developed in the early independence and late-20 $0^{\text {th }}$ century in contemporary reggae, particularly in ways that remind of the essentializing discursive features or intrinsic details that stand reggae apart.

\footnotetext{
xxxii See Ibid.

xxxiii Ibid.

xxxiv See King and Jensen for extensive analysis of Bob Marley's reggae lyrics.
} 


\section{Conclusion}

Contemporary reggae, while a postmodernist form for its innovations in electronic music and aestheticizations, is not estranged from the reggae tradition, especially of spirituality and protest. Its thematics and metaphors are uniquely reflective of roots reggae's defining features. The ways and manner of exhibiting those concerns do not show extended deviation in the way postmodernism seems to activate the deviant impulse within modernism that breaks away from tradition.

What is more interesting is the fact that reggae is traced back to Africa and rightly so. As it is obvious, the slaves that worked on the sugar plantations in the Caribbean were sourced from Africa and Asia. They were subjected to harsh treatment and no regard for human rights. The paper has been able to demonstrate how Reggae grew out of the slums into the hands of the Rasta to become a tool in the hands of social activists. The development of contemporary reggae from roots reggae, as highlighted in the body of the work, shows that music became opium for the suffering masses in Jamaica and the Caribbean during and after colonialism. Music was and is a form of escapism, which is why Reggae music carries so much emotionality.

The paper serves as a foundation for other works on reggae music in Jamaica (and the whole of Caribbean), especially from a postcolonial point of view.

\section{Conflict of Interest Statement}

The authors declare no conflicts of interests.

\section{About the Authors}

Dr. Chris Egharevba teaches African American, Caribbean and African Literature in the University of Uyo. He is a prolific writer, with over ten creative works to his credit.

Mr. Kufre Egharevba teaches African American, African Literature and literature and the New Media in the University of Uyo. He is a script writer and a film maker with lots of films to his credit.

\section{References}

Barry Peter. Beginning Theory: An Introduction to Literary and Cultural theory. Manchester: Manchester University Press, 2002.

Cuddon, John Anthony, Rafey Habib, and Matthew Birchwood. "A dictionary of literary terms and literary theory. Hoboken." (2013).

Davis Stephen and Peter Simon. Reggae Bloodlines. (New York: Anchor, 1977).

Henry William L. "Reggae, Rasta, and the Role of the Deejay in the British Black Experience". Contemporary British History 26.3 (2012): 355-373.

James Tracy. "Popular Communication and the Postcolonial Zeitgeist: On Considering Roots Reggae and Dub". Popular Communication 2.1 (2005): 21-41.

Järvenpää, Tuomas. Roots reggae from Cape Town to Helsinki: an ethnographic study of local belonging and cosmopolitan imagination in Rastafarian reggae music. Itä-Suomen yliopisto, 2017. 
King Stephen and Jensen Richard J. "Bob Marley's "Redemption Song": The Rhetoric of Reggae and the Rastafari" Journal of Popular Culture 29.3 (1995): 17-36.

Klages Mary. Literary Theory: A Guide for the Perplexed. New York: Continuous International Publishing Group, 2006.

Lyotard Jean-Francois. The Post-modern Condition: A Report of Knowledge. Massachusetts: University of Massachusetts Press, 1984.

Pryce Ken. Endless Pressure: A Study of West Indian Lifestyles in Bristol. Bristol: Bristol Classical Press, 1986. 154.

Robert E. Fox, "Diasporacentricism and Black Aural Texts", in The African Diaspora: African Origins and New World Identities, eds. Isidore Okpewho, Carole Davies and Ali Mazrui, 367-389. (Bloomington: Indiana University Press, 1984)

Winders James A. "Reggae, Rastafarians and Revolutions: Rock Music in the Third World". Journal of Popular Culture 17.1 (1983): 62-73. 

or adapt the article content, providing a proper, prominent and unambiguous attribution to the authors in a manner that makes clear that the materials are being reused under permission of a Creative Commons License. Views, opinions and conclusions expressed in this research article are views, opinions and conclusions of the author(s). and European Journal of Literature, Language and Linguistics Studies shall not be responsible or answerable for any loss, damage or liability caused in relation to/arising out of conflicts of interest, copyright violations and inappropriate or inaccurate use of any kind content related or integrated into the research work. All the published works are meeting the Open Access Publishing requirements and can be freely accessed, shared, modified, distributed and used in educational, commercial and non-commercial purposes under a Creative Commons Attribution 4.0 International License (CC BY 4.0). 